\title{
Analysis of Service Quality Dimensions on Customer Satisfaction at Semen Padang Hospital
}

\author{
Puspa Leni ${ }^{1}$, Sutiyem ${ }^{2}$, Suhery ${ }^{3}$, Dessy Trismiyanti ${ }^{4}$, Yoserizal $^{5}$ \\ ${ }_{1}^{1}$ STIE Perdagangan, Padang and Indonesia, $\square$ puspaleni@gmail.com \\ ${ }^{2}$ STIE Perdagangan, Padang and Indonesia $\square$ iyeksurti@yahoo.com \\ ${ }^{3}$ STIE Perdagangan, Padang and Indonesia, $\square$ suheriasia@gmail.com \\ ${ }^{4}$ STIE Perdagangan, Padang and Indonesia, $\square$ dessytrismiyanti@ymail.com \\ 5STIE Perdagangan, Padang and Indonesia, $\square$ yose.rizals@yahoo.co.id
}

\begin{abstract}
The purpose of this research is to analyze the effect of tangibles, reliability, responsiveness, and assurance on the customer satisfaction at Semen Padang Hospital. The sample size is 100 respondents. The sampling technique used was accidental sampling technique. The data collection was done by distributing the questionnaire. The data analysis used was multiple linear regression analysis. The research hypothesis employed the t-test, F-test, and the coefficient of determination test. The data processing was done by using SPSS. The results of the research show that tangibles and responsiveness partially have a positive and significant effect on customer satisfaction at Semen Padang Hospital, reliability and assurance do not determine the customer satisfaction in Semen Padang Hospital, and empathy variable does not affect the customer satisfaction at Semen Padang Hospital. Simultaneously, tangibles, reliability, responsiveness, assurance, and empathy have a positive and significant effect on the customer satisfaction at Semen Padang Hospital. The result of coefficient of determination test of the adjusted $\mathrm{R}$ square is $61 \%$, while the rest $39 \%$ is influenced by other variables not examined in this research. This means that all of the independent variables have an impact equal to $61 \%$ on the dependent variable of this research. Thus, it is concluded that to achieve customer satisfaction at Semen Padang Hospital, the quality of service needs to be improved, especially in terms of tangibles and responsiveness.
\end{abstract}

Keywords: customer satisfaction, tangibles, reliability, responsiveness, and assurance

\section{Introduction}

The quality of service is a very important part of the healthcare industry as the industry deals with realizing the customer satisfaction especially when it comes to the matter of life and death of a person. In an increasingly competitive environment, hospitals should be aware of the need to provide the best quality of service to their customers. The service industry is a different sector compared to the manufacturing sector. One example of the service sector is the healthcare industry such as the hospitals.

In the healthcare industry, hospitals provide the same types of services. However, it does not necessarily mean that the quality of service perceived by customers will be the same. The increasing number of hospitals in Padang, provides choices to the community. A good service is also a must if the hospital management wants to attract more patients. Law No. 8 of 1999 on consumer protection within the scope of health services by hospitals and Law No. 23 of 1992 on health state the legal consequences on the hospitals' and doctors' obligations and responsibilities in fulfilling the patient's right. The increasing of hospitals competition also affected the demands to improve the quality of hospital service. The competition that occurs is not only in terms of health equipment technology but also in terms of providing quality services. 
Hospital service quality is reflected as health service that fulfills patients' need as the hospital service user. As a result, the factors that affect the level of satisfaction of these patients should be acknowledged. People always expect that hospitals, both government and private, would provide satisfactory service to all of its users. Patients expect that hospitals provide good facilities and that they are assisted with hospitality in terms of responsiveness, the ability, and the dedication of the hospital staffs.

Satisfaction can affect customer evaluation of service quality. The importance of the issue has prompted efforts to clarify the relationship between satisfaction and quality of service (Parasuraman, et.al, 1985, 1988). The results of their study concluded that the higher the level of service quality perceived, the greater the customer satisfaction. This is due to the perceived quality of service which is the ability to decide on the perfection or superiority of an entity, or a form of attitude and a thorough evaluation in the long term.

Mauludin (2010: 67) suggests that the quality of service is the extent of the differences between the reality and the expectations of customers for the service that they receive or earn. Semen Padang Hospital is built to answer all the needs of the consumers in Padang with its vision of becoming the best public hospital at local and international level.

The service quality is examined from the dimensions of reliability, responsiveness, assurance, and tangibles (Parasuraman, 1988). These five dimensions are called service quality. The five dimensions of service quality can be described as follows: 1) tangibles (physical evidence) is a service that can be seen, smelled and touched, and tangibles is important in the service measurement. A customer will use his sense of sight to judge the quality of service. A good tangibles dimension affects the customer's perception. This tangibles dimension is also one of the aspects that affect customer expectations, because if the tangibles dimension is good, then the consumer expectation becomes higher; 2) reliability is a dimension that measures the reliability of the company in providing services to its customers. Compared to the other four dimensions of service quality (responsiveness, assurance, empathy and tangibles), this dimension is often perceived as the most important dimension for customers in various service industries. There are two aspects of this dimension: the company's ability to deliver the service as promised and the extent to which a company is able to provide accurate service with no error; 3 ) responsiveness is the most dynamic dimension of service quality. The customer's expectation of the speed of service will almost certainly change with the trends over time; 4 ) assurance is a quality dimension related to the company's ability and the frontline staff behavior in instilling trust and confidence in its customers; and 5) empathy is the fifth dimension of service quality. In general, this dimension is perceived as less important than the dimensions of reliability and responsiveness in the eyes of most customers.

The research results of Agung (2003) showed that tangibles (physical evidence) did not have a positive effect on the satisfaction of Sarila Husada Hospital Sragen's outpatients. This can be interpreted that if the equipment and infrastructures of Sarila Husada Hospital Sragen improve, then outpatients' satisfaction will not necessarily increase. The results showed that reliability had a positive and significant effect on the outpatients' satisfaction of Sarila Husada Hospital Sragen. This means that if the ability to provide immediate and satisfactory services that are in accordance with what is promised increase, then the outpatients' satisfaction at Sarila Husada Hospital Sragen will also increase. The results further showed that responsiveness had no positive or an insignificant effect on patient satisfaction of Sarila Husada Hospital Sragen. This can be interpreted that the employees' ability to help customers and provide services with responsiveness may not necessarily improve patient satisfaction Sarila Husada Hospital Sragen. The results of the analysis also showed that assurance has a positive and significant influence on patient satisfaction of Sarila Husada Hospital Sragen. This can be interpreted if the reliable nature of the employee increases, then the satisfaction of outpatients of Sarila Husada Hospital Sragen will also increase. 
Based on the phenomenon mentioned above, the hypotheses of this research are:

$\mathrm{H}_{1}$ Tangibles (Physical Evidence) dimension has a positive and significant impact on customer satisfaction at Semen Padang Hospital.

$\mathrm{H}_{2}$ Reliability has a positive and significant impact on customer satisfaction at Semen Padang Hospital.

$\mathrm{H}_{3}$ Responsiveness has a positive and significant impact on customer satisfaction at Semen Padang Hospital.

$\mathrm{H}_{4}$ Assurance has a positive and significant impact on customer satisfaction at Semen Padang Hospital.

$\mathrm{H}_{5}$ Empathy has a positive and significant impact on customer satisfaction at Semen Padang Hospital.

\section{Methods}

The type of research used in this study is quantitative research with associative research design. Sugiyono (2007) states that quantitative research is a study that aims to provide and describe a state or phenomenon that occurs at a certain time by using scientific procedures to answer the problem. Associative research is a research that questions the relationship between two or more variables that coincidentally emerged together (Sugiyono, 2003).

In this study, the independent variables are tangibles, reliability, responsiveness, empathy and assurance, while the dependent variable is customer satisfaction. The details are presented in Table 1.

Table 1 Operational definition of research variables

\begin{tabular}{|c|c|c|}
\hline Variable & Definition & Indicators \\
\hline $\begin{array}{l}\text { Customer } \\
\text { Satisfaction } \\
(\mathrm{Y})\end{array}$ & $\begin{array}{l}\text { Customer satisfaction is the feeling of } \\
\text { pleasure or disappointment that arises } \\
\text { because someone compares the } \\
\text { perceived performance of a product } \\
\text { (or outcome) to his expectations } \\
\text { (Kotler, 2000) }\end{array}$ & $\begin{array}{l}\text { 1. Satisfaction on the ability to carry } \\
\text { out promised services with accuracy } \\
\text { and reliability } \\
\text { 2. Satisfaction on the ability to assist } \\
\text { patients and provide responsive } \\
\text { services } \\
\text { 3. Satisfaction on the knowledge, } \\
\text { capability, courtesy, and credibility } \\
\text { skills of hospital staff } \\
\text { Satisfaction on the ease of creating } \\
\text { relationships, good communication, } \\
\text { personalized attention and } \\
\text { understanding the needs of the } \\
\text { patient } \\
\text { Satisfaction on the appearance of } \\
\text { physical facilities, equipment, } \\
\text { employees, and means of } \\
\text { communication (developed from } \\
\text { Agung Utama's research, 2003) }\end{array}$ \\
\hline $\begin{array}{l}\text { Tangibles } \\
(\mathrm{X} 1)\end{array}$ & $\begin{array}{l}\text { Physical evidence is a service that can } \\
\text { be seen, smelled and touched, and } \\
\text { tangibles dimension is important in } \\
\text { service measurement. }\end{array}$ & $\begin{array}{ll}- & \text { Parking space } \\
\text { - } & \text { a comfortable customer waiting room } \\
\text { - } & \text { treatment room } \\
\text { - } & \text { clean bed sheet } \\
\text { - } & \text { clean bathroom } \\
\text { - } & \text { decor } \\
\text { - } & \text { tariff list } \\
\text { - } & \text { list of service types } \\
\text { - } & \text { medical officers' tidiness } \\
- & \text { quality of food }\end{array}$ \\
\hline
\end{tabular}




\begin{tabular}{|c|c|c|}
\hline Variable & Definition & Indicators \\
\hline $\begin{array}{l}\text { Reliability } \\
(\mathrm{X} 2)\end{array}$ & $\begin{array}{l}\text { Reliability is a dimension that } \\
\text { measures the reliability of the } \\
\text { company in providing services to its } \\
\text { customers. }\end{array}$ & $\begin{array}{ll}\text { - } & \text { Quickly make corrections } \\
\text { - } & \text { Reliable and consistent } \\
\text { - } & \text { Providing services as needed } \\
\text { - } & \text { Provide a list of types of health } \\
& \text { services }\end{array}$ \\
\hline $\begin{array}{l}\text { Responsiveness } \\
(\text { X3) }\end{array}$ & $\begin{array}{l}\text { Responsiveness is the most dynamic } \\
\text { dimension of service quality. The } \\
\text { customer's expectation of the speed of } \\
\text { service will almost certainly change } \\
\text { with the trends over time. }\end{array}$ & $\begin{array}{ll}\text { - } & \text { Speedy response of medical } \\
\text { personnel } \\
\text { - } \\
\text { Medical officers have an orderly } \\
\text { schedule of patient condition control } \\
\text { - } \\
\text { A fast response in fulfilling } \\
\text { customer's wishes }\end{array}$ \\
\hline $\begin{array}{l}\text { Assurance } \\
(X 4)\end{array}$ & $\begin{array}{l}\text { Assurance is a quality dimension } \\
\text { related to the company's ability and } \\
\text { front-line staff behavior in instilling } \\
\text { trust and confidence in its customers. }\end{array}$ & 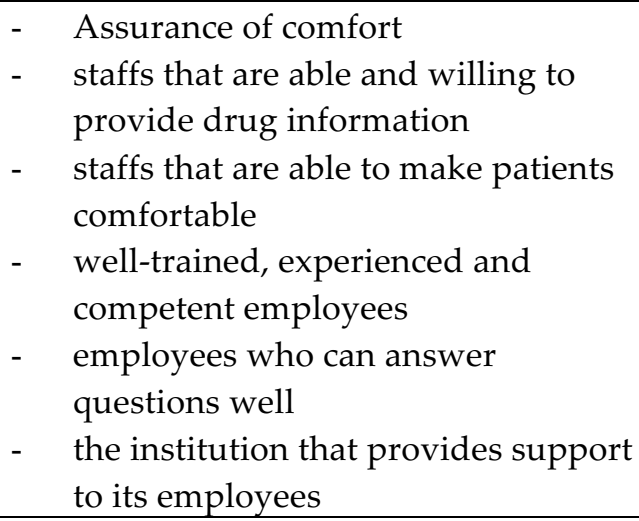 \\
\hline Empathy (X5) & $\begin{array}{l}\text { Empathy is the fifth dimension of } \\
\text { service quality. In general, this } \\
\text { dimension is perceived as less } \\
\text { important than the dimensions of } \\
\text { reliability and responsiveness in the } \\
\text { eyes of most customers. }\end{array}$ & 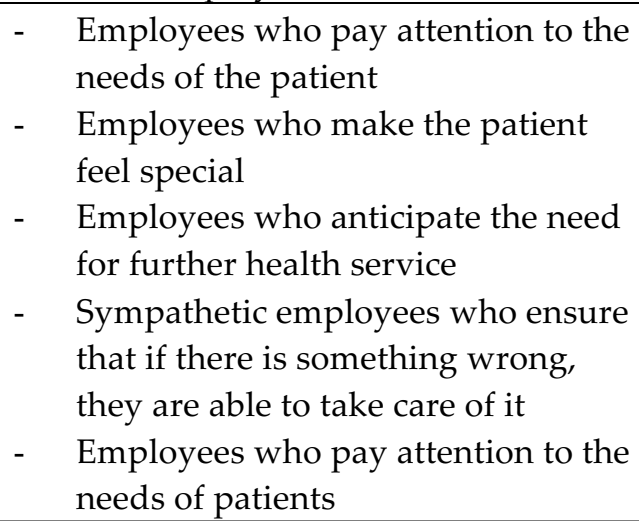 \\
\hline
\end{tabular}

Indicators of service quality developed by Steven and Patton (1995) Dinerserve a Tool for Measuring Service Quality in Hospital "Cornell Hospital" (in Fuad, 2004)

The sample in this research is the patients at Semen Padang Hospital amounted to 100 people. The sampling technique used the accidental sampling technique due to an unknown number of the population. To answer the research hypothesis, the data analysis technique used is multiple linear regression analysis using SPSS version 17.0.

\section{Results and Discussion}

To find out the extent to which the regression coefficient of each independent variable and the direction of the influence on the dependent variable, the analysis of multiple regression data obtained by using the program SPSS Version 17 is shown in Table 2. 
Table 2 Results of multiple regression analysis

\begin{tabular}{|c|c|c|c|c|c|}
\hline \multirow{3}{*}{ Variable } & \multirow{2}{*}{\multicolumn{2}{|c|}{$\begin{array}{l}\text { Unstandardized } \\
\text { Coefficients }\end{array}$}} & \multirow{3}{*}{$\begin{array}{c}\text { Standardized } \\
\text { Coefficients }\end{array}$} & \multirow{3}{*}{$\mathrm{T}$} & \multirow{3}{*}{ Sig. } \\
\hline & & & & & \\
\hline & $\mathrm{B}$ & $\begin{array}{l}\text { Std. } \\
\text { Error }\end{array}$ & & & \\
\hline Constanta (a) & 0.945 & 0.307 & & 3.074 & 0.003 \\
\hline Tangibles $\left(\mathrm{X}_{1}\right)$ & 0.468 & 0.102 & 0.446 & 4.596 & 0.000 \\
\hline Reliability $\left(\mathrm{X}_{2}\right)$ & 0.067 & 0.091 & 0.086 & 0.741 & 0.460 \\
\hline Responsiveness $\left(\mathrm{X}_{3}\right)$ & 0.240 & 0.074 & 0.356 & 3.251 & 0.002 \\
\hline Assurance $\left(X_{4}\right)$ & 0.091 & 0.105 & 0.098 & 0.869 & 0.387 \\
\hline Empathy $\left(X_{5}\right)$ & -0.079 & 0.087 & -0.102 & -0.917 & 0.362 \\
\hline
\end{tabular}

Source: Result of Primary Data Processing (2018)

Based on regression results from Table 2 above, the multiple linear regression equation in this study is determined as follows:

$$
\mathrm{Y}=0.945+0.468 \mathrm{X}_{1}+0.067 \mathrm{X}_{2}+0.240 \mathrm{X} 3+0.091 \mathrm{X} 4-0.079 \mathrm{X} 5+0.307
$$

in which:

Y: customer Satisfaction

a: constants

$\mathrm{b}_{1}$ : tangibles regression coefficient

$X_{1}$ : tangibles

$\mathrm{b}_{2}$ : reliability regression coefficient

$\mathrm{X}_{2}$ : reliability

$b_{3}$ : responsiveness regression coefficient

$\mathrm{X}_{3}$ : responsiveness

$\mathrm{b}_{4}$ : assurance regression coefficient

$\mathrm{X}_{4}$ : assurance

$b_{5}$ : empathy regression coefficient

X: empathy

e: error

The interpretation of the regression equation obtained is as follows. First, the constant is 0.945 indicates that without tangibles $\left(X_{1}\right)$, Reliability $\left(X_{2}\right)$ responsiveness $\left(X_{3}\right)$, assurance $\left(X_{4}\right)$, and empathy $\left(X_{5}\right)$, customers remain satisfied with the quality of service at Semen Padang Hospital. Second, the tangibles regression coefficient $\left(\mathrm{X}_{1}\right)$ has a positive sign that is 0.468 , which means that if there is an increase related to tangibles given to the patient, then the customer satisfaction at Semen Padang Hospital will also increase. Third, the regression coefficient of reliability $\left(X_{2}\right)$ is equal to 0,067 and is marked positive, which means that if there is an improvement related to reliability given to the patient, then the customer satisfaction at Semen Padang Hospital will also increase. Fourth, the regression coefficient of Responsiveness $\left(\mathrm{X}_{3}\right)$ is 0.240 with a positive sign, which means that if there is an increase associated with Responsiveness given to the patient, then the customer satisfaction at Semen Padang Hospital will also increase. Fifth, the regression coefficient of assurance (X4) is 0,067 and is marked positive, which means that if there is an increase related to assurance given to the patient, then the customer satisfaction at Semen Padang Hospital will also increase. Sixth, the regression coefficient of empathy (X5) is $-0,079$ with a negative sign, which means that if there is an increase related to Assurance given to the patient, then the customer satisfaction in Semen Padang Hospital will also decrease.

The t-test is done to examine the hypotheses formulated in this study by looking at the significance value in the coefficient table as seen in Table 2 above. The $t$-test results of each independent variable on the dependent variable show that the value of $t$ table is seen by measuring the degrees of freedom (df) determined by the formula $\mathrm{n}-\mathrm{k}$, in which $\mathrm{n}=$ the number of observations, while $\mathrm{k}=$ number of 
variables (independent and dependent variables) with $\alpha=0.05(5 \%)$. To determine the degree of freedom (df) of this test, then $n-k=100-6=94$, and the value of $t$ table $=1.66123$.

The results show that the $t$-count of tangibles is $4.596>t$ - table (1.66123) and the significance value is 0.000 . Thus, $\mathrm{H}_{1}$ is supported. These results indicate that there is a positive and significant influence on the tangibles and the customer satisfaction at Semen Padang Hospital.

The $\mathrm{t}$-count of reliability is $0.741<\mathrm{t}$ table $(1.66123)$ with the sig. value of $0.460>0.05$. Thus, $\mathrm{H}_{2}$ is supported. These results indicate that there is an insignificant relation between reliability and the customer satisfaction at Semen Padang Hospital. Hence reliability does not determine customer satisfaction in Semen Padang Hospital.

The $t$-count of responsiveness is $3.251>t$ table $(1.66123)$ and sig. value of $0.002<0.05$. Thus, $\mathrm{H}_{3}$ is supported. These results show that responsiveness has a positive and significant impact on the customer satisfaction at Semen Padang Hospital.

The $\mathrm{t}$-count of assurance is $0.869<\mathrm{t}$ table $(1.66123)$ and sig. value $0.387>0.05$. Thus, $\mathrm{H} 4$ is not supported. These results indicate that assurance does not determine the customer satisfaction at Semen Padang Hospital.

The $\mathrm{t}$-count of Empathy is $-0.917<\mathrm{t}$ table $(1.66123)$ and sig. value $0.362>0.05$. Thus, H5 is not supported. These results indicate that empathy has a negative and insignificant effect on the customer satisfaction at Semen Padang Hospital. Hence, empathy is not a variable that determines customer satisfaction in Semen Padang Hospital.

The coefficient of determination $\left(R^{2}\right)$ test is a test to find the contribution of all independent variables $(\mathrm{X})$ to the dependent variable $(\mathrm{Y})$ where $0<\mathrm{R}_{2}<1$. If the value of $\mathrm{R}$ is closer to 1 , then the influence of independent variables $(X)$ on the related variables $(Y)$ is stronger. On the contrary, if the value is closer to 0 , then the influence is weaker. Table 3 below shows the results of coefficient of determination (R2) test.

Table 3 Model summary

\begin{tabular}{cc}
\hline Model & $\begin{array}{c}\text { Adjusted } \\
\text { R Square }\end{array}$ \\
\hline 1 & 0.610
\end{tabular}

Source: SPSS Data (2018)

From Table 3 above, it is seen that the value of adjusted R2 is equal to 0.610. It can be interpreted that service quality dimensions of tangibles, reliability, responsiveness, assurance and empathy affect the variable of customer satisfaction with the percentage of $61 \%$, while the rest $39 \%$ is influenced by other variables not examined in this research.

\section{The Effect of Tangibles Dimension on Customer Satisfaction at Semen Padang Hospital $\left(\mathrm{H}_{1}\right)$}

Tangibles (X1) has a partially positive and significant effect on the customer satisfaction in Semen Padang Hospital. This means that if tangibles dimension, i.e. parking space, a comfortable customer waiting room, treatment room, clean bed sheet, clean bathroom, decor, tariff list, list of service types, medical officers' neatness, and the quality of the food increase, then the customer satisfaction at Semen Padang Hospital will also increase. The result of this study is in line with the research conducted by Agung (2003) that tangibles dimension has a positive and significant impact on customer satisfaction of General Hospital Cakra Husada Klaten.

\section{The Effect of Reliability on Customer Satisfaction at Semen Padang Hospital $\left(\mathrm{H}_{2}\right)$}

Reliability has no significant effect on the customer satisfaction at Semen Padang Hospital. Thus, reliability does not determine the customer satisfaction at Semen Padang Hospital. The result of this 
study is not in line with the research conducted by Agung (2003) that reliability has a positive and significant impact on customer satisfaction of General Hospital Cakra Husada Klaten.

\section{Effect of Responsiveness on Customer Satisfaction at Semen Padang Hospital $\left(\mathrm{H}_{3}\right)$}

Responsiveness has a positive and significant impact on the customer satisfaction at Semen Padang Hospital. This means that if the response of medical personnel is fast, the medical officers have an orderly schedule of patient condition control and a fast response in fulfilling customer's wishes, and then the customer satisfaction at Semen Padang Hospital will increase. The result of this study is in line with the research conducted by Agung (2003) from that responsiveness has a positive and significant impact on customer satisfaction of General Hospital Cakra Husada Klaten.

\section{The Effect of Assurance on Customer Satisfaction at Semen Padang Hospital $\left(\mathrm{H}_{4}\right)$}

Assurance does not have a significant effect on the customer satisfaction in Semen Padang Hospital, which means that in this research assurance does not determine the customer satisfaction in Semen Padang Hospital. The result of this research is not in line with research conducted by Agung (2003) that assurance has a positive and significant effect on customer satisfaction of General Hospital Cakra Husada Klaten.

\section{The Effect of Empathy on Customer Satisfaction at Semen Padang Hospital $\left(\mathbf{H}_{5}\right)$}

Empathy has a negative and insignificant effect on the customer satisfaction at Semen Padang Hospital, so empathy is not a variable that determines the customer satisfaction in Semen Padang Hospital. The result of this study is not in line with the research conducted by Agung (2003) that empathy has a positive and significant impact on customer satisfaction of General Hospital Cakra Husada Klaten.

\section{Conclusions}

The purpose of this research is to analyze the effect of tangibles, reliability, responsiveness, and assurance on the customer satisfaction at Semen Padang Hospital. The research data were collected using a survey questionnaire. The sample was selected using accidental sampling techniques resulted with 100 sample. The data analysis used was multiple linear regression analysis.

The results of this research are as follows. First, tangibles as a service dimension has a positive and significant impact on the customer satisfaction at Semen Padang Hospital. If tangibles dimension of the hospital is good, then the customer satisfaction at Semen Padang Hospital will increase. On the contrary, if the tangibles dimension decreases, then the customer satisfaction in Semen Padang Hospital will decrease. Second, reliability does not determine the customer satisfaction at Semen Padang Hospital. Third, responsiveness has a positive and significant impact on the customer satisfaction at Semen Padang Hospital. If the responsiveness can be improved, then customer satisfaction at Semen Padang Hospital will increase. On the contrary, if responsiveness decreases, then the customer satisfaction in Semen Padang Hospital will also decrease. Fourth, assurance does not determine the customer satisfaction at Semen Padang Hospital. Finally, empathy is not a variable that affects the customer satisfaction at Semen Padang Hospital.

\section{Acknowledgments}

We would like to thanks to Department of Management, Sekolah Tinggi Ilmu Ekonomi Perdagangan which has funded this research and all those involved in the completion of the research.

\section{References}

Kotler, P. (2000). Marketing Management. New Jersey: Prentice Hall.

Mas'ud, F. (2004). Survai Diagnosis Organisasional (Konsep dan Aplikasi). Semarang: Badan penerbit Universitas Diponegoro. 
Mauludin, H. (2010). Marketing research: Panduan bagi Manajer, Pimpinan Perusahaan Organisasi. Jakarta: Elex Media Komputindo.

Parasuraman, A., Zeithaml, V. A. and Berry, L.L (1985), A Conceptual Model of Service Quality and Its implications for future research. Journal of Marketing, 4(41).

Parasuraman, A., Zeithaml, V.A. and Berry, L.L (1988), SERVQUAL: A multiple item scale for measuring consumer perceptions of service quality. Journal of Retailing, 4(1).

Sugiyono. (2003). Metode Penelitian Bisnis. Bandung: Pusat Bahasa Depdiknas.

Sugiyono. (2007). Statistika untuk Penelitian. Bandung: Alfabeta.

Utama, A. (2003). Analisis Pengaruh persepsi kualitas pelayanan terhadap kepuasan pelanggan Rumah Sakit Umum Cakra Husada Klaten. OPSI, 1(2), 96 -110. 